\title{
Symptoms among Chilli Grinders
}

\author{
C. G. URAGODA \\ From the Chest Clinic, Kandy, Ceylon
}

In countries where the consumption of chillies is high, the grinding of dried red chillies into a fine powder is a new industry. The majority of workers employed in this process suffer from sneezing, watering of the nose, and cough, all of which are maximal at the beginning of their employment. They develop tolerance within a variable period, after which this triad of symptoms occurs only when the atmosphere becomes heavily contaminated with chilli-powder or on inhalation of the volatilized capsaicin which is liberated when the roasted chillies are being ground. A burning sensation of the skin also occurs in most of the workers, especially when the skin is moist. Loss of weight is another common feature. All these symptoms are temporary, last only during the period of exposure, and do not produce radiological changes.

Chilli is the pod-like fruit of the small herbaceous shrub, capsicum, of which there are several species. It is grown in many tropical regions, such as India, the West Indies, Africa, Ceylon, and tropical America. The less pungent variety, paprika, is cultivated extensively in Hungary (Pearson, r962). The fruits of many species of capsicum, such as $C$. frutescens and C. minimum, have a pungent taste which makes them an essential ingredient in the preparation of tropical dishes. This pungency excites the appetite, although such dishes taste burning hot to the uninitiated palate. The pungent principle in chillies is capsaicin. Capsicum B.P.C. is used medically as a carminative and as an external irritant.

Chillies, which are green when raw, become bright red on ripening due to a mixture of carotenoid pigments. In tropical countries, chillies are dried in the hot sun, when they become light and papery while still retaining the pungency and the red colour. The powdered dried chilli is widely used in the preparation of curries. Until a few years ago, dried chillies were usually powdered in the kitchen for the use of the individual household, but in recent years, in Ceylon, the grinding of dried chillies into powder has become a minor industry. It is done by electrically- or fuel-operated machines established in almost every town. Each mill employs three to eight workers, but, in view of the large number of units scattered throughout the country, the number of workers in this occupation must be considerable.

I have not been able to trace any reference in the literature to ill health among chilli grinders. The following study was made to ascertain whether workers in this recent industry are subject to any

Received for publication July 26, 1966. form of ill health that could be attributed to the nature of their occupation, especially in view of the irritant quality of the material with which they deal.

\section{Method and Material}

Six chilli-grinding mills in the city of Kandy were selected for the present study. They were all licensed annually with the Kandy Municipal Council. Through the good offices of the Medical Officer of Health, Kandy, the workers in these mills were requested to attend the Chest Clinic in Kandy. Nineteen workers out of a total of 2 I employed were examined. A detailed history was taken, special emphasis being given to their period of employment as chilli grinders. Besides a physical examination, a radiograph of the chest, white and red cell counts, and a haemoglobin estimation were done. In cases where sputum was available, a microscopic examination was carried out to detect any particles resembling chilli-powder.

\section{Description of the Process}

Each establishment had two or more electricallyoperated grinding machines working side by side. The chillies were fed into a conical-shaped trough in the machine and came out as a powder via a large nozzle. The grinding process was repeated twice more to reduce the particle size.

Different establishments had various ways of increasing the ventilation. Many of them had several large windows fitted in the room where the machines were housed. The windows were supplemented by a gap between the top of the walls and the roof. One establishment had unusually high walls, thus increasing the cubic capacity of the room.

\section{Results}

All the workers were men and, at the time of the present study, were currently employed in powdering chillies. Their ages ranged from 19 to 40 years, 
the average being 29 years. The newest recruit had worked for six months, while the oldest hand had served for Io years as a chilli grinder. The average period of employment was four years nine months.

Every worker questioned had had certain symptoms which had appeared for the first time after he had taken up his new occupation. These symptoms occurred either singly or in combination (Table I). The combination of sneezing, watering of the nose, and cough occurred in 18 men (95\%), only one worker being free of them. In 17 of the 18 men, these symptoms were most prominent at the beginning of employment and became less noticeable after a time as they continued with their work. Since these mills started between two and 15 years ago, only two men had been forced to leave on account of the severity of these initial symptoms.

\section{TABLE I}

FREQUENCY OF SyMPTOMS

\begin{tabular}{l|c|c}
\hline Symptom & No. of Cases & $\%$ \\
\hline Sneezing & I8 & 95 \\
Watering of nose & 18 & 95 \\
Cough & 18 & 95 \\
Burning sensation & 18 & 95 \\
Loss of weight & I I & 58 \\
Cold lasting longer & 2 & I I \\
Tightness of chest & 2 & I I \\
Haemoptysis & I & 5 \\
\hline
\end{tabular}

In three men (16\%) the initial symptoms were very severe, but in five $(27 \%)$ they were so mild that the men were hardly troubled by them. The initial symptoms lasted in different subjects from three days to six months, the average being one month and three weeks (Table II).

Once the initial symptoms had subsided, they did not recur at all in three out of the 18 men. The remaining 15 men got the same symptoms in a much milder form, but only when a breeze blowing through the windows disseminated the chillipowder into the atmosphere of the room, or while grinding roasted chillies.

An equally common symptom was a burning sensation of the body, occurring in 18 men ( $95 \%$ ). This symptom occurred mainly when the skin was moist with either sweat or water.

Eleven men $(58 \%)$ experienced loss of weight which began on taking up this occupation. Five were unable to say exactly how many pounds they had lost, but the remaining six had lost from 3 to $20 \mathrm{lb}$. ( $\mathrm{I} \cdot 3$ to $9 \mathrm{~kg}$.), the average being $10.5 \mathrm{lb}$. $(4 \cdot 7 \mathrm{~kg}$.).
TABLE II

INCIDENCE OF SNEEzing, WATERING OF Nose, AND COUgh, THEIR DEgreE OF INTENSITY AND DURATION

\begin{tabular}{|c|c|c|c|c|}
\hline Case & Age & $\begin{array}{l}\text { Period of } \\
\text { Work }\end{array}$ & $\begin{array}{l}\text { Degree of } \\
\text { Intensity }\end{array}$ & $\begin{array}{l}\text { Duration of } \\
\text { Initial } \\
\text { Symptoms }\end{array}$ \\
\hline $\begin{array}{l}1 \\
2 \\
3 \\
4 \\
5\end{array}$ & $\begin{array}{l}40 \\
24 \\
23 \\
25 \\
26\end{array}$ & $\begin{array}{l}3 \text { yrs. } 2 \text { mths. } \\
\text { I yr. } 6 \text { mths. } \\
6 \text { yrs. } \\
8 \text { yrs. } \\
7 \text { yrs. }\end{array}$ & $\begin{array}{l}\text { Moderate } \\
\text { Severe } \\
\text { Severe } \\
\text { Moderate } \\
\text { Moderate }\end{array}$ & $\begin{array}{l}\text { I wk. } \\
2 \text { mths. } \\
2 \text { wks. } \\
2 \text { mths. } \\
2 \text { mths. }\end{array}$ \\
\hline 6 & 19 & 2 yrs. & Moderate & 3 mths. \\
\hline 7 & 29 & Io yrs. & Mild & $\begin{array}{l}\text { No initial } \\
\text { intensity }\end{array}$ \\
\hline 8 & 34 & 7 yrs. & Moderate & 3 mths. \\
\hline 9 & 27 & 7 yrs. & Moderate & I mth. \\
\hline I0 & 35 & 2 yrs. 7 mths. & & \\
\hline I I & 20 & 3 mths. & Moderate & I mth. \\
\hline 12 & 23 & 4 yrs. 6 mths. & Severe & I mth. \\
\hline 13 & 34 & 8 yrs. & Mild & 6 mths. \\
\hline 14 & 34 & 3 yrs. & Moderate & 3 mths. \\
\hline 15 & 27 & 6 mths. & Moderate & 2 mths. \\
\hline 16 & 32 & Io yrs. & Mild & 3 days \\
\hline 17 & 35 & 9 yrs. & Moderate & 2 wks. \\
\hline 18 & 21 & 6 mths. & Mild & 3 days \\
\hline 19 & 23 & I yr. 6 mths. & Mild & 3 days \\
\hline
\end{tabular}

Two men complained of tightness of the chest, and another two said that when they got a cold it lasted longer than previously. There was no alteration in the frequency of respiratory infections as a result of their work. One worker gave a history of haemoptysis four years previously. It had lasted seven days, but investigations at the time had failed to reveal the cause.

Only one person had abnormal physical signs, consisting of bilateral scattered rhonchi. These were the result of an acute bronchitis secondary to influenza. All had normal radiographs of the chest. In eight men, the sputum contained microscopic particles which resembled chilli-powder in size and colour. The white and red cell counts and haemoglobin content of the blood were within normal limits.

\section{Discussion}

An occupational disease among paprika workers in Hungary has been described (Hunter, 1955). Paprika is a mildly pungent variety of capsicum. The fruits are sometimes infested with the fungus Mucor stolonifer. Women are employed to split these fruits in order to remove the ribs containing 
the pungent principle prior to grinding. During the process of splitting, the fungus is liberated and is inhaled. The workers may suffer from loss of weight, poor appetite, poor sleep, and even haemoptysis, and there may be signs of bronchitis. In the chronic form, the workers may develop pulmonary fibrosis and bronchiectasis. It is thought that the fungus is the aetiological factor. Those workers grinding the split fruit and those handling the finished powder have no symptoms. Once the ribs have been removed prior to grinding, there is a lack of pungency. It is not surprising, therefore, that grinders of paprika are free from any irritative symptoms.

The chillies used in tropical countries are quite different in that they are very pungent. Chillipowder is a very irritant vegetable dust. In its action, it appears to be in the same category as irritant gases, such as ammonia, sulphur dioxide, and chlorine (Jones, 1952), which act merely as superficial irritants to the respiratory mucosa. They produce discomfort and temporary disability but have not been proved to produce cumulative effects. In the present study there were no instances of permanent respiratory disability such as chronic bronchitis, emphysema, or pulmonary fibrosis among the workers examined, even though some of them were chilli grinders of nine or 10 years' standing.

It is clear that when they first take to chilligrinding the majority of workers suffer from sneezing, watering of the nose, and cough. These symptoms follow a definite pattern; they are maximal at the onset. After a varying period, each worker develops a tolerance to the irritant quality of the powder, being hardly bothered by it, and is free of symptoms when away from work. This tolerance is only relative, as the symptoms return when the atmosphere becomes rapidly contaminated with a high concentration of chilli-powder as a result of a sudden blowing into the room. The symptoms also recur when roasted chillies are being ground. When chillies are roasted, capsaicin volatilizes into an extremely irritant gas. Some of this gas is trapped within the chillies and is liberated on grinding.

As long as the workers were actively engaged in chilli-grinding, they suffered from a burning sensation of the body, especially when their skin became moist with water or sweat, which acts as a vehicle for the powder.

Loss of weight appears to be a significant feature, but the reason for this is difficult to find. The subjects' appetites were good, and the amount of manual work that chilli-grinding entailed was hardly consistent with such a loss of weight. In this context, it is interesting to note that paprikasplitters, too, lost weight sometimes. One man regained his weight on terminating his employment. When, dfter an interval of five years, he resumed his work as a chilli grinder, he lost weight again, suggesting that loss of weight also may be a temporary feature of employment as a chilli grinder.

None of the workers examined had any abnormal physical signs except for one man with a recent acute bronchitis. Radiographs of the chest were all normal. It is unlikely that chilli-grinding induces any permanent pulmonary damage.

I am much indebted to Dr. K. C. D. Perera, Medical Officer of Health, Kandy, for his ready co-operation and assistance which made this study possible.

\section{REFERENCES}

Hunter, D. (1955). The Diseases of Occupations. English Universities Press, London.

Jones, A. T. (1952). Proc. roy. Soc. Med., 45, 609.

Pearson, D. (1962). The Chemical Analysis of Food, 5th ed. Churchill, London. 